\title{
A Phytopharmacological review of a Mediterranean plant: Lavandula stoechas L
}

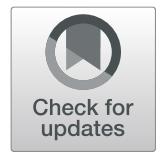

Yassine Ez zoubi ${ }^{1,2^{*}}$ D, Dalila Bousta ${ }^{3}$ and Abdellah Farah ${ }^{2}$

\begin{abstract}
The Mediterranean region is characterized by a diverse vegetation cover, and the Lavandula genus is one of the most important medicinal and aromatic plants in this region. It has been used in traditional medicine as a treatment for anxiety and insomnia and to improve sleep quality for a long history. Lavender is commonly used in perfumes, soaps, bath powders, and scented sachets. It can flavor teas or food even at low concentrations. Several ethnopharmacological studies have demonstrated its use in treating several diseases; it has anti-inflammatory, antioxidant, antispasmodic, sedative, insecticidal, antimicrobial and antifungal activities. This paper reviews the geographical distribution, traditional uses, chemical composition, and pharmacological activities of the Lavandula stoechas.
\end{abstract}

\section{Introduction}

Six thousand years ago, several ancient civilizations in present-day Egypt, China and India began to use aromatic and medicinal plants to treat diseases and for spiritual purposes [21, 43]. Although the use of medicinal herbs for therapeutic purposes is a practice as old as the history of mankind, aromatherapy has undergone an important evolution during the twenty-first century, enabling the development of a science of aromatherapy [26]. This herbal remedy has shown considerable value in treating diseases using extracts from aromatic and medicinal plants, including essential oils, alcoholic and hydrolic extracts, fruit juices, and extracts distilled from resins $[22,81]$.

The flora of the Mediterranean area includes many aromatic and medicinal species that have long been an integral part of the local culture, covering an extensive area with different environmental conditions [4, 21, 24, 64]. The Mediterranean population has been a depository for endogenous knowledge that it has been acquired empirically through the generations.

Among the medicinal plants used in the Mediterranean basin, the species belonging to the Lamiaceae, Asteraceae, and Apiaceae families are the most common

\footnotetext{
*Correspondence: y.ezzoubi@uae.ac.ma; ezzoubiyassine@yahoo.fr

${ }^{1}$ Biotechnology, Environmental Technology and Valorization of Bio-resources team, Department of Biology, Faculty of Science and Technology

Al-Hoceima, Abdelmalek Essaadi University, Ajdir 32003 Tetouan, Morocco

${ }^{2}$ Laboratory of Applied Organic Chemistry, Faculty of Sciences and

Technology, Sidi Mohamed Ben Abdellah University, Po.Box 2202, - Route

d'Imouzzer, Fez, Morocco

Full list of author information is available at the end of the article
}

in this region [53]. Some of thes, including sage, rosemary $[20,38]$, thyme [36], oregano [44], lavender [45, 54] and other Lamiaceae species [50,54,58], have already been studied for their pharmacological activities.

The synonyms of Lavandula L., according to Upson (2002), are Stoechas Mill., Fabricia Adans., Chaetostachys Benth., Sabaudia Buscal. and Muschl. and Isinia Rech. f. The genus Lavandula is composed of approximately 39 species, many hybrids, and nearly 400 registered cultivars (Upson \& Andrews 2004). The best-known and economically valued species are $L$. angustifolia, $L$. stoechas, L. latifolia and the L. $\mathrm{x}$ intermedia hybrid.

Plants in the Lavandula genus are sub-shrubs or sometimes perennial shrubs up to one meter in height. They are in full bloom between mid-June and mid-July and prefer acidic soils. Inflorescence is common to the Lavandula genus. The flowers, with pedicel, are arranged in whorls and held in clusters of cylindrical or quadrangular cymes. They often are purple, blue, violet (Fig. 1), pink or lilac. The L. stoechas was likely the first to be used for their essential oils. The Romans, Greeks, and Arabs all recognized their medicinal properties [58].

L. stoechas is a well-known plant species and is used throughout the Mediterranean region for its medicinal virtues, mainly attributed to its essential oil content. It is also used for the preparation of traditional meals and herbal teas, and for cosmetic purposes [60,91].

According to ethnobotanical and phytopharmacological studies, L. stoechas is used in Morocco to treat 

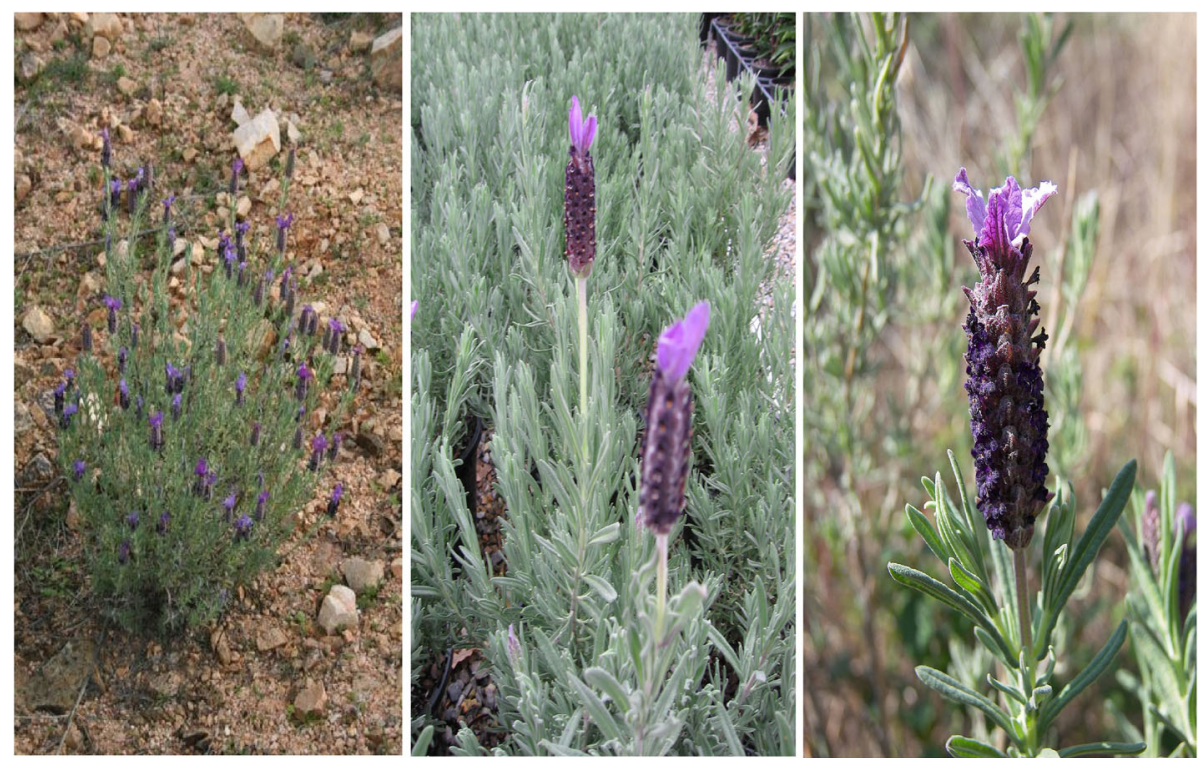

Fig. 1 L. stoechas plants from Taounate city /Morocco

rheumatic diseases and nephrotic syndromes, as an antispasmodic agent, and to reduce pain and inflammatory problems $[25,27]$.

Several researchers are interested in the pharmacological effects of $L$. stoechas essential oils and extracts, and have evaluated their antibacterial [29], antifungal, insecticidal, anti-leishmanial [14], antioxidant [28, 57], and antiinflammatory properties $[12,28]$. However, other potentials pharmacological effects of this oil have not yet been evaluated.

The present review provides a comprehensive summary of the ethnobotanical and ethnophamacological uses, chemical composition and biological activities of $L$. stoechas.

\section{Geographical distribution}

L. stoechas is spread over three continents (Africa, Europe and Asia). It is growing around the Mediterranean basin, including in Morocco, Algeria, Tunisia, Spain, Greece, France, Italy, and Turkey. It is also found in Saudi Arabia and Iran (Fig. 2) [85]. In Morocco, this plant typically grows at high altitudes on calcareous soils, especially in the north of Morocco, in the middle and high Atlas and Rif mountains. In Tunisia, it is distributed in the north, north-east and Cap Bon regions at altitudes from 400 to $1000 \mathrm{~m}$ [39]. According to Mohd et al. [58], L. stoechas is also found in Bihar and Bengal in India. It has been introduced throughout Europe and to temperate/subtemperate areas in the Americas, Asia, and Australia [47].

\section{Traditional uses}

L. stoechas is a well-known species used throughout the Mediterranean region for its medicinal virtues such as its cephalic (tonic), and carminative properties. It is prescribe to treat pulmonary infections and inflammatory diseases (Table 1). The plant is also used in folk medicine as an antispasmodic in colic pain and for various diseases of the central nervous system, such as epilepsy and migraine.

L. stoechas also has positive effects on wounds, urinary tract infections, against eczema, and has analgesic, sedative and antiseptic properties. It is also, used as a culinary herb to prepare a particular type of couscous, to flavor certain traditional meals, and to prepare tea and soup [12, 60, 91]. In the Maghreb countries, such as Morocco, Algeria, and Tunisia, this plant is used in the traditional pharmacopeia to treat headaches, depression, diabetes, and inflammatory and rheumatic diseases [12, $25,75]$.

In the Palestinian tradition, the decoction of the areal part of lavender is used to treat migraine and epilepsy [32]. The flower infusion is used in Turkish phytotherapy as an expectorant, antispasmodic, carminative, menstrual regulari, stimulant, deobstruent, resoluent and wound healing agent [82].

\section{Phytochemical screening}

Many phenolics have been identified in the Lavandula genus, including protocatechuic, caffeic, ferulic, chlorogenic and rosmarinic acids, pinobanksin, pinocembrin, quercetin and luteolin [46].

Among the numerous chemical compounds known in L. stoechas, Ez Zoubi et al. [27] revealed the presence of several chemical families in the hydroethanolic extract, 


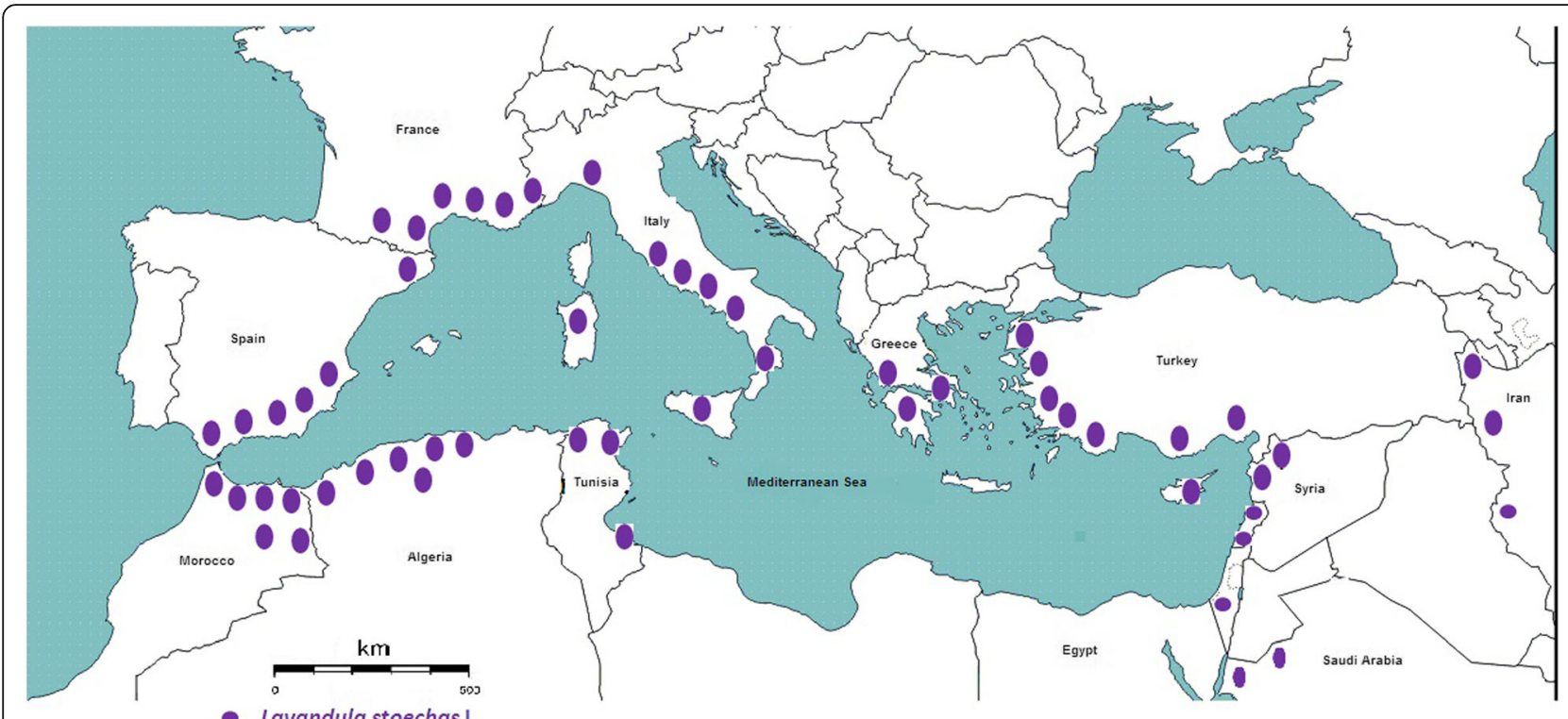

Fig. 2 Geographic Distribution from L. stoechas

such as flavonoids, catechic tannins, sterols, coumarins, leucoanthocyans and mucilages. Lavandula antineae Maire was found to produce flavonoids and tannins [80] and Lavandula officinalis L. was found to contain coumarins [5]. Xavier et al. [88] revealed the presence of apigenin 7-glucoside, luteolin, luteolin 7-glucoside, and luteolin 7glucuronide. The main constituents of flavonoids in the leaves of the species $L$. stoechas are simple flavone glycosides (flavone di-O-glycosides and flavone 7-Omonoglycosides). The following compounds have been detected in the areal parts of $L$. stoechas extracts: oleanolic, ursolic and vergatic acids; $\beta$-sitosterol; $\alpha$-amyrin; $\alpha$ amyrin acetate; lupeol; erythrodiol; luteolin; acacetin; vitexin; two longipinane derivatives (longipin-2-ene-7 $\beta$,
$9 \alpha$-diol-1-one and longipin-2-ene-7 $\beta, 9 \alpha$-diol-1-one-9monoacetate); 7-methoxy coumarin; and lavanol ([87]; Manzoor et al. 1969).

\section{Chemical constituents of $L$. stoechas essential oils}

The terpenic compound of the species $L$. stoechas have been determined in different Mediterranean countries (Algeria, Greece, Spain, Corsica, Turkey, Morocco, Tunisia, etc), with variable results (Table 2). Fenchone, camphor, and 1,8-cineole compounds are the most commonly identified major compounds. Several studies have shown that the fenchone/camphor chemotype are the major compounds in L. stoechas essential oils ([12]; Angioni et al. 2006). Carrasco et al. (2015) distinguished

Table 1 Ethnomedicinal uses of L. stoechas in some Mediterranean countries

\begin{tabular}{|c|c|c|c|c|c|}
\hline Countries & Local names (ethnic) & Plant parts used & Traditional uses & Preparation form & References \\
\hline Algeria & Halhal & Aerial part & $\begin{array}{l}\text { Analgesic } \\
\text { Teeth }\end{array}$ & Infusion & {$[73]$} \\
\hline Greece & $\left.\mathrm{N}\right|^{*}$ & Leaves & $\begin{array}{l}\text { Anti-diabetes, menstrual pains, kidney } \\
\text { stones, carbuncles, otitis and hyper-tension. }\end{array}$ & Infusion and essential oils & {$[78]$} \\
\hline Iran & Ossoghodus & Leaves & $\begin{array}{l}\text { Anticonvulsant, Sedative } \\
\text { Antispasmodic }\end{array}$ & Infusion & {$[62]$} \\
\hline Morocco & Halhal & Aerial part & $\begin{array}{l}\text { Rheumatism, system digestive, cystitis and } \\
\text { nephritis }\end{array}$ & Decoction & {$[25]$} \\
\hline Pakistan & Ustu khuddoos & Aerial part & Epilepsy and migraine & Decoction & {$[32]$} \\
\hline Portugal & Rosmaninho & Aerial part & $\begin{array}{l}\text { For heart-burn, for sea-sickness, blood } \\
\text { circulation andsedative }\end{array}$ & Infusion & {$[16,63]$} \\
\hline Spain & $\begin{array}{l}\text { Cantueso, cap díase, } \\
\text { bofarull }\end{array}$ & Flowered aerial part & As herbal tea and for making liqueur & Infusion & {$[84]$.} \\
\hline Turkish & Karabaş & Flowering branches & $\begin{array}{l}\text { Expectorant, menstrual regulari, antispasmodic } \\
\text { and carminative }\end{array}$ & Infusion & {$[67,84]$} \\
\hline
\end{tabular}


Table 2 Major constituents of volatile oils from L. stoechas

\begin{tabular}{|c|c|c|c|c|}
\hline Countries & $\begin{array}{l}\text { Parts of } \\
\text { plants }\end{array}$ & Majors compounds & $\begin{array}{l}\text { Total } \\
\text { compounds }\end{array}$ & References \\
\hline Algeria & Flowers & $\begin{array}{l}\text { - Linalyl Acetate } \\
\text { (15.26\%) } \\
\text { - Camphor (11.25\%) } \\
\text { - y-Terpinene }(11.2 \%) \\
\text { - Linalool }(10.68 \%) \\
\text { - 1,8-Cineole }(10.25 \%)\end{array}$ & 49 & [11] \\
\hline Greece & Leafs & $\begin{array}{l}\text { - Fenchone (44.8\%) } \\
\text { - 1,8-Cineole (16.7\%) } \\
\text {-a-Cardinol (7.2\%) } \\
\text {-Camphor (6.2\%) }\end{array}$ & 62 & {$[56]$} \\
\hline Italy & Aerial parts & $\begin{array}{l}\text {-Fenchone }(37.0 \%) \\
\text {-Camphor }(27.3 \%) \\
\text {-Bornyl acetate (6.2\%) } \\
\text { - 1,8 Cineole }(6 \%)\end{array}$ & 22 & [91] \\
\hline Morocco & Aerial parts & $\begin{array}{l}\text {-Fenchone }(30.5 \%) \\
\text {-Camphor }(18.2 \%) \\
\text {-1,8-Cineole }(8.6 \%) \\
\text {-Camphene }(3.5 \%)\end{array}$ & 27 & [90] \\
\hline Pakistan & Aerial parts & $\begin{array}{l}\text { - Camphor (46.24\%) } \\
\text {-Borneol (6.71\%) } \\
\text { - Caryophyllene } \\
\text { (4.72\%) } \\
\text { - 1,8-Cineole (3.69\%) }\end{array}$ & 13 & [89] \\
\hline Portugal & Aerial parts & $\begin{array}{l}\text {-Fenchone (41.9\%) } \\
\text { - Camphor (34.6\%) } \\
\text { - linalool (2.7) }\end{array}$ & 42 & [30] \\
\hline Spain & Aerial parts & $\begin{array}{l}\text { - Fenchone (37\%) } \\
\text {-1,8-Cineole (17.8\%) } \\
\text {-Camphor (15.6\%) } \\
\text { - Linalool (7.5\%) }\end{array}$ & 50 & [2] \\
\hline Tunisia & Aerial parts & $\begin{array}{l}\text {-Fenchone (34.3\%) } \\
\text { - Comphor (27.4\%) } \\
\text { - Lavandulyl acetate } \\
\text { (5.6\%) } \\
\text {-1,8-Cineole (3.4\%) }\end{array}$ & 33 & {$[57]$} \\
\hline Turkey & Flowers & $\begin{array}{l}\text { - Fenchone }(32.03 \%) \\
\text { - Camphor (14.71\%) } \\
\text {-Myrtenyl acetate } \\
(11.7 \%) \\
\text { - 1,8-Cineole }(7.67 \%)\end{array}$ & 34 & {$[82]$} \\
\hline
\end{tabular}

fenchone (37\%), camphor (15.6\%), and 1,8-cineole $(17.8 \%)$. In addition to fenchone, camphor, and 1,8-cineole compounds, the oils of $L$. stoechas from Greece were found to contain $\alpha$-cardinol (7.2\%) [56]. The main components of Moroccan L. stoechas oils were found to be fenchone (30.5\%), camphor (18.2\%), 1,8-cineole (8.6\%), and camphene (3.5\%) [90]. Camphene, linalyl acetate, $\gamma$ terpinene, linalool, lavandulyl acetate, myrtenyl acetate, bornyl acetate, borneol and caryophyllene were found as the major compounds in some reports (Fig. 3).

However, the absence of some of the compounds mentioned above led to the identification of different biochemotypes of $L$. stoechas. The chemotype found by Topal et al. [86] was characterized by the absence of volatile compounds such as $\alpha$-pinene, limonene, myrtenyl acetate, and viridiflorol. Gursoy et al. [35] detected the presence of p- cymene, a compound rarely found in the samples of Turkish essential oils. Alpha-pinene and viridiflorol are the compounds commonly found in samples of essential oils grown in Italy, Turkey and Algeria; in addition, caryophyllene oxide is a characteristic compound of essential oils of Turkish and Algerian origins [2].

The aroma profile of $L$. stoechas growing in Corsica revealed a significant variation of the major compounds, including fenchone (14.9\% to $75.5 \%)$, camphor (2.5\% to $56.2 \%)$, and 1,8 -cineole $(0.17 \%$ to $8 \%$ ) [69]; this differentiation was explained by the longitudinal variation of the varieties studied ([69]; Nicolas et al. 1998). Finally, these variations in chemical profile could be explained by different environmental conditions, geographical origins, parts of the plant that were extracted, and extraction methods [52, 61, 68].

\section{Pharmacological activities Anti-inflammatory effects}

The anti-inflammatory effects of $L$. stoechas were evaluated by inducing inflammation via a lipopolysaccharidemacrophage model. The results of this in vitro study showed that $L$. stoechas essential oil in concentrations of $0.16 \mu \mathrm{L} / \mathrm{mL}$ and $0.32 \mu \mathrm{L} / \mathrm{mL}$ significantly reduced nitrite production in cell cultures without causing cellular damage [91].

In another experimental model, Algieri et al. [3] found an anti-inflammatory effect of $L$. stoechas extraction, with values similar to those recorded by a steroidal antiinflammatory drug (glucocorticoid dexamethasone). Rats treated with the L. stoechas extract in doses of $10 \mathrm{mg} / \mathrm{kg}$ and $25 \mathrm{mg} / \mathrm{kg}$ exhibited reduced inflammation of the tissues by $1 \mathrm{~cm}$ to $2 \mathrm{~cm}$; the anti-inflammatory effect was explained by the regulation of inflammatory precursors, including matrix metalloproteinase 9, inducible nitric oxide synthase, cyclooxygenase 2 , and pro-inflammatory cytokines.

L. stoechas extract was also shown to exhibit inhibitory activity in paw edema induced by carrageenan; however, it had no effect on 12-O-tetradecanoylphorbol 13-acetate (TPA) induced ear edema [6]. A concentration of $200 \mu \mathrm{g} /$ $\mathrm{mL}$ was shown to decrease pro-inflammatory cell viability by $63 \%$ after $3 \mathrm{~h}$ of incubation. Neutrophil elimination through apoptosis could be implicated in the resolution of acute inflammation, whereas the reduction of reactive oxygen species produced by neutrophils, such as the superoxide anion and the hydroxyl radical, could be implicated in the overall reduction of inflammation. Ez Zoubi et al. [27] demonstrated that treatment with the hydroethanolic extract of the aerial part of $L$. stoechas (10\%) induces a significant decrease in paw volume of rats, with a reduction in paw volume of $74 \pm 7 \%$, compared with diclofenac used as a control anti-inflammatory $(69 \pm 10.3 \%)$. Flavonoid and mucilage extracts significantly reduced edema by $85.1 \pm$ $6.2 \%$ and $61.71 \pm 7.3 \%$, respectively, indicating that 


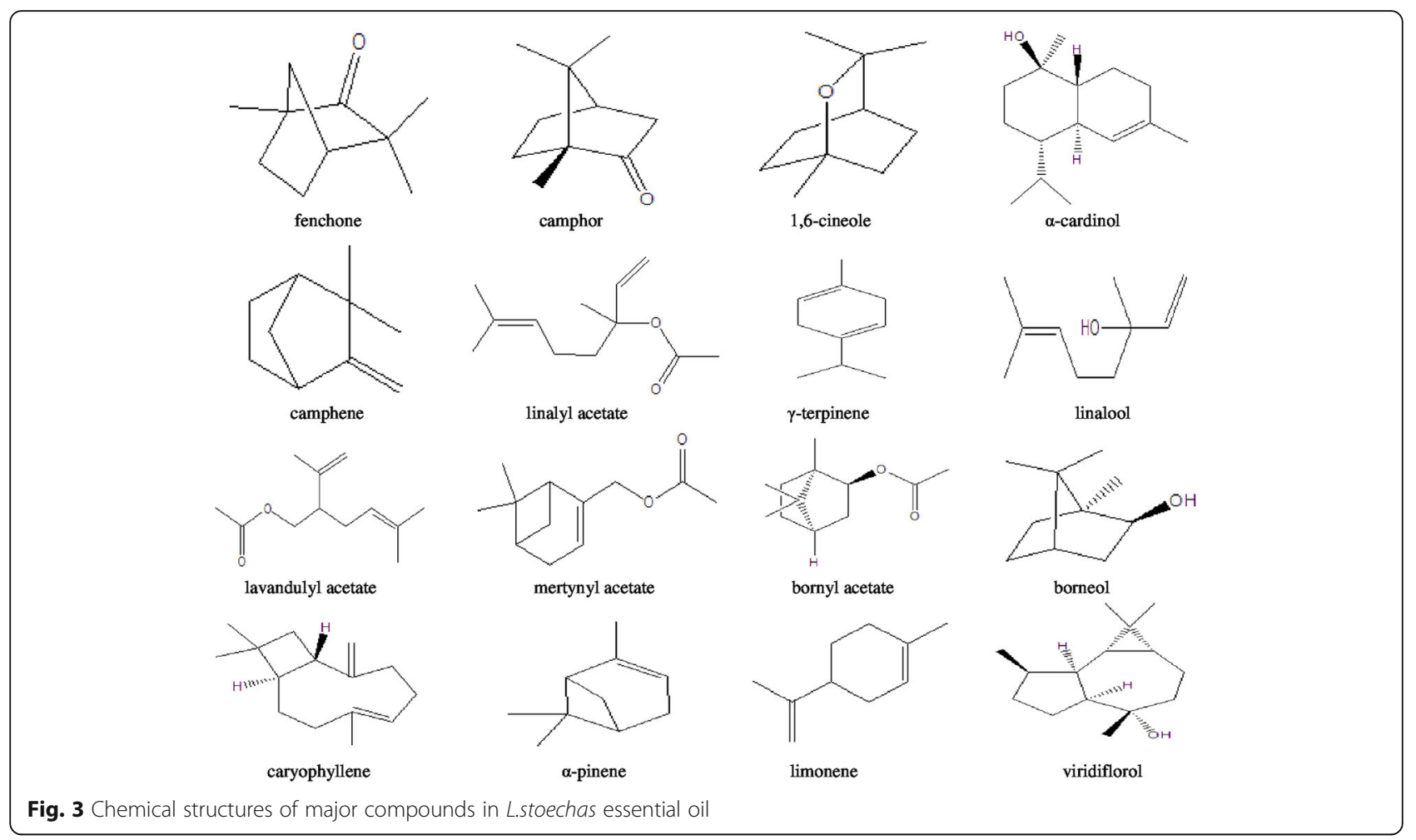

flavonoids and mucilages in $L$. stoechas extract may be responsible for the observed anti-inflammatory effects.

\section{Antioxidant effect}

The antiradical potency of the L. stoechas extract grown in Morocco was tested using the 2,2-diphenyl-1-picrylhydrazyl (DPPH) scavenging assay [28]. At concentrations of $4 \mathrm{mg} / \mathrm{mL}, \quad 2 \mathrm{mg} / \mathrm{mL}$, and $1 \mathrm{mg} / \mathrm{mL}$, the hydroethanolic extract decreased the DPPH signal by $85.5 \%, 57.8 \%$, and $44 \%$, while butylated hydroxytoluene (synthetic antioxidant) decreased the signal by $78.3 \%$, $73.0 \%$, and $65 \%$. The half maximal inhibitory concentration (IC50) of the extract in this study was $1400 \mu \mathrm{g} / \mathrm{mL}$ higher than BHT $(\mathrm{IC} 50=200 \mu \mathrm{g} / \mathrm{mL})$.

Ceylana et al. [18] evaluated the anti-radical activity of the methanolic extract of $L$. stoechas and recorded an IC50 of $300 \mu \mathrm{g} / \mathrm{mL}$, compared with BHT and BHA with IC50 values of $200 \mu \mathrm{g} / \mathrm{mL}$ and $100 \mu \mathrm{g} / \mathrm{mL}$, respectively. In a comparative study by Sariri et al. [72], the water extracts of four lavender species from the north of Iran were studied to investigate theirpotency as tyrosinase inhibitors. The study showed a variable antioxidant power of the four Lavandula species, with antiradical values of $9.2 \mu \mathrm{g} / \mathrm{mL}, 12.5 \mu \mathrm{g} / \mathrm{mL}, 38.7 \mu \mathrm{g} / \mathrm{mL}$, and $65.1 \mu \mathrm{g} / \mathrm{mLfor}$ $L$. angustifolia, $L$. stoechas, $L$. dentate, and $L$. latifolia, respectively. Sebai et al. [75] evaluated the antioxidant activity using the radical-scavenging activity and DPPH methods, which revealed that the volatile compounds of L. stoechas were characterized by a high antioxidant capacity (IC50 $=221.43 \mu \mathrm{g} / \mathrm{mL})$, although this was lower than that of the control antioxidant (ascorbic acid, IC50 $=87.57 \mu \mathrm{g} / \mathrm{mL}$ ).

Messaoud et al. [57] reported an IC50 value of $2321.7 \mu \mathrm{g} /$ $\mathrm{mL}$ in Tunisian L. stoechas essential oils. Moreover, Barkat and Laib [11] found an IC50 of $584 \pm 0.58 \mu \mathrm{g} / \mathrm{mL}$ in Algerian $L$. stoechas essential oils from dry flowers. A large number of studies carried out on the antiradical activity of plant extracts have shown that phenolic compounds, particularly flavonoids, are potentially antioxidant substances with the capacity to trap free radicals $([7,9,66])$.

Carrasco et al. (2015) demonstrated that linalool and thymol compounds are responsible for the antioxidant activity of $L$. stoechas essential oils. Phenolic acids and flavonoids in $L$. stoechas such as rutin and caffeic acid also have antioxidant activity [7].

The antioxidant characteristics of the phenolic compounds in L. stoechas are mainly attributed to their ability to eliminate free radicals; for example, they reduce oxidative stress induced in diabetic rats [74] and have hepatoprotective and renoprotective effects against malathioninduced oxidative stress in young male mice [76].

\section{Antispasmodic and sedative effects}

The anti-spasmodic effect of $L$. stoechas extract was evaluated on rabbit jejunum [32]. The authors recorded an anti-spasmodic effect of doses between $0.1 \mathrm{mg} / \mathrm{mL}$ and $1.0 \mathrm{mg} / \mathrm{mL}$ of $L$. stoechas hydromethanolic extracts without recording a negative effect on the jejunum 
tissues. This spasmolytic activity may be due to the presence of 7-methoxycoumarin, which has been reported to be a smooth muscle relaxant [51]. In the same study, Gilani et al. [32] demonstrated that the extract of $L$. stoechas has sedative properties at a dose of $600 \mathrm{mg} / \mathrm{kg}$; pentobarbital sleeping time was prolonged from $39.4 \pm 5.74 \mathrm{~min}$ to $65.4 \pm 5.72 \mathrm{~min}$, similar to diazepam, a standard sedative drug [40]. The tested rats were calm, dull, and relaxed. This study provides evidence for the traditional usage of this plant as a sedative.

\section{Antibacterial activity}

Many essential oils exhibit antibacterial and antiviral activities and have been shown to be potent therapeutic agents. These oils are used against both pathogenic and non-pathogenic organisms [77]. Cherrat et al. [19] reported that Moroccan $L$. stoechas essential oils showed superior antibacterial activity against Gram-positive bacteria compared with Gram-negative bacteria; for example, they exhibited the highest antimicrobial activities against Escherichia coli O157, Listeria monocytogenes and Staphylococcus aureus with inhibition diameters of $16.2 \pm 0.60 \mathrm{~mm}, 32.0 \pm 2.00 \mathrm{~mm}$ and $28.0 \pm 0.70 \mathrm{~mm}$, respectively. Sarac and Ugur [71] recorded the antibacterial activity of $L$. stoechas essential oil cultivated in Turkey against both Gram-positive and Gram-negative bacteria. S. aureus, S. epidermidis, S. mutans, E. coli, P. stutzeri, S. maltophilia, M. luteus, C. luteola, and B. subtilis were the most sensitive bacteria to the essential oil and are antibiotic-resistant bacteria.

L. stoechas essential oils from Turkey (Goren et al. [34]) and Tunisia [15] both showed strong antimicrobial activity, similar to other sesquiterpene rich essential oils. A recent study tested antimicrobial activity against eight pathogenic bacterial strains, including E. coli, S. aureus, $L$. monocytogenes, Proteus mirabilis, Pseudomonas aeruginosa and B. subtilis using amicrotitration assay [14]. The study indicated that the highest inhibition was obtained against $L$. monocytogenes and $S$. aureus with inhibition diameters of $23 \pm 0.85 \mathrm{~mm}$ and $21 \pm 0.25 \mathrm{~mm}$, respectively.

Camphor and 1,8-cineole, among the major compounds in L. stoechas oils, have an antibacterial effect, especially against $S$. aureus, E. coli and L. monocytogenes [37, 48, 79].

Several studies showed that minor components in the $L$. stoechas essential oils have synergistic antimicrobial activity [33, 59]. Gram-positive bacteria were more susceptible to the essential oils than Gram-negative bacteria, likely due to outer membrane differences $[15,42,65]$.

\section{Antifungal activity}

Several studies have evaluated the antifungal activity of $L$. stoechas essential. Benabdelkader et al. [12] evaluated the antifungal activity of $11 \mathrm{~L}$. stoechas essential oils and confirmed the presence of antifungal activity against filamentous fungi (Aspergillus niger and Fusarium oxysporum) and yeasts (Candida albicans). Similarly, L. stoechas essential oils tested on filamentous fungi and molds had antifungal activity on various strains of clinical origin (Candida albicans, Candida krusei, and Candida guilliermondii) and on clinical dermatophytes (Epidermophyton floccosum and Trichophyton mentagrophytes), with inhibition zones between $0.32 \mu \mathrm{l} / \mathrm{ml}$ and $5 \mu \mathrm{l} / \mathrm{ml}$ [91].L. stoechas essential oils also demonstrated antifungal activity against Rhizoctonia solani and Fusarium oxysporum, but had less effect on Aspergillus flavus (Angioni et al. 2006). The antifungal activity of $L$. stoechas essential oils has been reported to be specifically related to the presence of antifungal compounds such as camphor, 1,6-cineole, and fenchone, and the synergistic effect of the major and minor constituents of this oil $[12,91]$.

\section{Insecticidal and larvicidal activities}

The use of insecticides and chemical larvicides is currently the most popular technique for controlling insects. However, the intensive use of these insecticides has caused contamination of the food chain and the appearance of resistant insects. The use of molecules and extracts of botanical origin appear to be the best alternative to fight against insects and larvae (Isman 2000). El Ouali Lalami et al. [23] found that L. stoechas essential oil has a positive effect against Anopheles labranchiae, a vector for malaria transmission, with a lethal dose of $500 \mathrm{mg} / \mathrm{ml}(\mathrm{LC} 50=112.51 \mathrm{mg} / \mathrm{L} ; \mathrm{LC} 90=294.51 \mathrm{mg} / \mathrm{L})$.

Bouyahya et al. [14] tested the effects of $L$. stoechas essential oil on three species of Leishmania using the MTT (3(4.5-dimethylthiazol-2yl)-2,5-diphenyltetrazolium bromide) assay. This study revealed LC50 of $0.9 \pm 0.45 \mu \mathrm{g} / \mathrm{mL}, 7 \pm$ $0.54 \mu \mathrm{g} / \mathrm{mL}$ and $>10 \mu \mathrm{g} / \mathrm{mL}$ against Leishmania major, Leishmania infantum and Leishmania tropic, respectively.

Camphor, which is one of the majors components detected in L. stoechas essential oil, is known to have insecticidal activities $[49,55]$. Indeed, camphor showed interesting antileishmanial activity against $L$. major $($ IC50 $=$ $5.55 \pm 1.27 \mu \mathrm{g} / \mathrm{mL}$ ) and L. infantum (IC50 = $7.90 \pm 0.42 \mu \mathrm{g} /$ $\mathrm{mL})$. Camphene and 1,8-cineol, which are major constituents of $L$. stoechasessential oils, were reported to be toxic for several insect species $[8,55,70]$. Moreover, 1,8-cineol showed a good larvicidal activity against Aedes aegypti [17].

\section{Cytotoxic activity}

Gören et al. [34] evaluated the cytotoxicity of L. stoechas essential oils against cancer cell lines including KB (human epidermoid carcinoma), LNCaP (hormone-dependent human prostate cancer), BC1 (human breast cancer), P388 (mouse leukemia), LU1 (human lung cancer), COL-2 (human colon cancer), and KV-B (+VLB) (drug-resistant KB). The essential oils were active against COL-2 and weakly 
active against LNCaP; P388 cells were very sensitive to the chloroform extract of $L$. stoechas.

\section{Other pharmacological activities}

Several ethnobotanical studies have reported the use of L. stoechas to treat diabetes or to reduce the level of hyperglycemia [10, 13, 41, 83]. However, few studies evaluated the anti-glycemic effect of the $L$. stoechas extract and essential oil [31, 75]. An in vivo study conducted by Sebai et al. [75] on the antidiabetic activity of L. stoechas essential oil revealed a protective effect against hyperglycemia and oxidative stress.

\section{Conclusion}

The biological activities of $L$. stoechas essential oils and extracts described in this review are mainly due to the plant's richness in bioactive molecules belonging to several chemical families, such as phenolics, flavonoids and monoterpenoids. These compounds possess pharmacological properties, including antispasmodic, sedative, anti-inflammatory, antioxidant, antimicrobial, antifungal, insecticidal, and larvicidal activities. Compounds from $L$. stoechas with a wide array of bioactivities can serve as lead compounds for drug development. In-depth phytopharmacological and phytochemical studies are needed to highlight the relationship between secondary metabolites and observed biological effects. Additional experimental studies that could substantiate and describe the correlation of the isolated phytochemicals from L. stoechas with their corresponding pharmacological effects are also needed.

Based on the different pharmacological effects illustrated in this review, we can conclude that this plant, abundant in the Mediterranean basin and not exploited, could attract the intention of the scientific community to conduct more in-depth analyses, especially clinical studies, in order to identify the molecule or molecules that have phytopharmacological power.

\section{Acknowledgements}

Not applicable.

\section{Authors' contributions}

Dalila bousta, selection, arrangement and compilation of suitable material. Farah Abdellah, relevant literature search. Yassine z zoubi, supervising the whole work.

All authors read and approved the final manuscript.

\section{Funding}

No funding.

\section{Availability of data and materials}

The datasets supporting the conclusions of this article are included with in the article.

Ethics approval and consent to participate Not applicable.
Consent for publication

Not applicable.

\section{Competing interests}

There authors declare that they have no competing interest.

\section{Author details}

${ }^{1}$ Biotechnology, Environmental Technology and Valorization of Bio-resources team, Department of Biology, Faculty of Science and Technology

Al-Hoceima, Abdelmalek Essaadi University, Ajdir 32003 Tetouan, Morocco.

${ }^{2}$ Laboratory of Applied Organic Chemistry, Faculty of Sciences and

Technology, Sidi Mohamed Ben Abdellah University, Po.Box 2202, - Route

d'Imouzzer, Fez, Morocco. ${ }^{3}$ Laboratory of Neuroendocrinology and

Nutritional and Climatic Environment, Faculty of Sciences Dhar El Mehraz,

University of Sidi Mohamed Ben Abdellah, Fez, Morocco.

Received: 30 May 2019 Accepted: 11 December 2019

Published online: 11 February 2020

\section{References}

1. Aburjai T, Hudaib M, Tayyem R, Yousef M, Qishawi M. Ethnopharmacological survey of medicinal herbs in Jordan, the Ajloun Heights region. J Ethnopharmacol. 2007;110:294-304.

2. Alejandro C, Vanessa OR, Ramiro MG, Virginia T, Jose T. Lavandula stoechas essential oil from Spain: aromatic profile determined by gas chromatography-mass spectrometry, antioxidant and lipoxygenase inhibitory bioactivities. Indus Crop Prod. 2015;73:16-27.

3. Algieri F, Rodriguez-Nogales A, Vezza T, Garrido-Mesa J, Garrido-Mesa N, Pilar Utrilla M, et al. Anti-inflammatory activity of hydroalcoholic extracts of Lavandula dentate L. and Lavandula stoechas L. J Ethnopharmacol. 2016;190: 142-58

4. Ali-Shtayeh MS, Jamous RM, Al-Shafie JH, El Gharabah WA, Kherfan FA, Qarariah KH, Khdair IS, et al. Traditional knowledge of wild edible plants used in Palestine (northern West Bank): a comparative study. J Ethnobiol Ethnomed. 2008;12:4-13

5. Al-Niaame AE, Raghad AA. Study of Lavandula officinalis L. buds of flowers extracts activity against some species of multi-drug resistant clinical isolates of bacteria. Iraqi J Biotechnol. 2013;12(2):82-91.

6. Amira S, Dade M, Schinella G, Ríos JL. Anti-inflammatory, antioxidant and apoptotic activities of four plant species used in folk medicine in the Mediterranean basin. Pak J Pharm Sci. 2012;25(1):65-72.

7. Apak R, Güçlü K, Özyürek M, Karademir SE. Novel total antioxidant capacity index for dietary polyphenols and vitamins $C$ and $E$, using their cupric ion reducing capability in the presence of neocuproine: CUPRAC method. J Agric Food Chem. 2004;52(26):7970-1981.

8. Baotong L. Bioactivity of camphor against the long-horned beetles (Anoplophora chinensis and Nadezhdiella cantori). Acta Phytophylacica Sinica. 2003;30(2):166-70.

9. Barazandeh MM. Essential oil composition of Lavandula latifolia Medik from Iran. J Essent Oil Res. 2002;14:103-4.

10. Barkaoui M, Katiri A, Boubaker H, Msanda F. Ethnobotanical survey of medicinal plants used in the traditional treatment of diabetes in Chtouka Ait Baha and Tiznit (Western anti-atlas), Morocco. J Ethnopharmacol. 2017; 198:338-50.

11. Barkat M, LAIB I. Antioxidant activity of the essential oil from the flowers of Lavandula stoechas. J Pharmacogn Phytother. 2012;4(7):96-101.

12. Benabdelkader T, Zitouni A, Guitton Y, Jullien F, Maitre D, Casabianca H, Legendre L, Kameli A. Essential oils from wild populations of Algerian Lavandula stoechas L.: composition, chemical variability, and in vitro biological properties. Chem Biodivers. 2011;8:937-53.

13. Bouayyadi L, El Hafian M, Zidane L. Étude floristique et ethnobotanique de la flore médicinale dans la région du Gharb, Marocco. J Appl Biosci. 2015;93: 8760-9.

14. Bouyahya A, Et-Touys A, Abrini J, Talbaoui A, Fellah H, Bakri Y, Dakka N. Lavandula stoechas essential oil from Morocco as novel source of antileishmanial, antibacterial and antioxidant activities. Biocatal Agric Biotechnol. 2017:12:179-84.

15. Bouzouita N, Kachouri F, Hamdi M, Chaabouni MM. Volatile constituents and antimicrobial activity of Lavandula stoechas L. oil from Tunisia. J Essent Oil Res. 2005;17:584-6. 
16. Camejo-Rodrigues J, Ascensão L, Àngels Bonet M, Vallès J. An ethnobotanical study of medicinal and aromatic plants in the Natural Park of "Serra de São Mamede" (Portugal). J Ethnopharmacol. 2003;89:199-209.

17. Cavalcanti ESB, de Morais SM, Lima MAA, Santana EWP. Larvicidal activity of essential oils from Brazilian plants against Aedes aegypti L. Mem Inst Oswaldo Cruz. 2004;99:541-4.

18. Ceylana Y, Ustab K, Ustab A, Maltasc E, Yildiz S. Evaluation of antioxidant activity, phytochemicals and ESR analysis of Lavandulas stoechas. Acta Phys Pol A. 2015;128:483-7.

19. Cherrat L, Espina L, Bakkali M, Pagán R, Laglaoui A. Chemical composition, antioxidant and antimicrobial properties of Mentha pulegium, Lavandula stoechas and Satureja calamintha Scheele essential oils and an evaluation of their bactericidal effect in combined processes. Innov Food Sci Emerg Technol. 2014;22:221-9.

20. Cuvelier ME, Richard H, Berset C. Antioxidative activity and phenolic composition of pilot-plant and commercial extracts of sage and rosemary. J Am Oil Chem Soc. 1996;73:645-52.

21. Dhayalan M, JI A, Nagendra GN. Biological activity sources from traditionally used tribe and herbal plants material. Asian J Pharm Clin Res. 2015;8(6):11-23.

22. Dunning T. Aromatherapy: overview, safety and quality issues. OA Altern Med. 2013;1(1):1-6.

23. El Ouali LA, El-Akhal F, Maniar S, Ez zoubi Y, Taghzouti K. Chemical constituents and Lanvicidal activity of essential oil of Lavandula stoechas (Lamiaceae) from Morocco against the malaria vector Anopheles Labranchiae (Diptera: Culicidae). Int J Pharmacognosy Phytochem Res. 2016;8(3):505-11.

24. El-Darier SM, El-Mogaspim M. Ethnobotany and relative importance of some endemic plant species at El-Jabal El-Akhdar region (Libya). World J Agric Sci. 2009;5:353-60.

25. El-Hilaly J, Hmammouchi M, Lyoussi B. Ethnobotanical studies and economic evaluation of medicinal plants in Taounate Province (northern Morocco). J Ethnopharmacol. 2003:86:149-58.

26. Esposito ER, Bystrek MV, Klein JS. An elective course in aromatherapy science. Am J Pharm Educ. 2014;78(4):79.

27. Ez zoubi Y, Bousta D, El Mansouri L, Boukhira S, Siham L, Achour S, Farah A. Phytochemical screening, anti-inflammatory activity and acute toxicity of hydro-ethanolic, flavonoid, Tannin and Mucilage Extracts of Lavandula stoechas L from Morocco. Int J Pharmacognosy Phytochem Res. 2016;8(1):31-7.

28. Ez zoubi Y, Bousta D, Lachkar M, Farah A. Antioxidant and anti-inflammatory properties of Ethanolic extract of Lavandulas stoechas L. from Taounate region in Morocco. Int J Phytopharmacol. 2014;5(1):21-6.

29. Ez zoubi Y, El Ouali Lalami A, Bousta D, Polissiou M, Daferera D, Lachkar M, El Khanchoufi A, Farah A. Chemical composition, antioxidant and antimicrobial activities of the essential oil and its fractions of Lavandula stoechas L. From Morocco. Int J Curr Pharm Rev Res. 2017;8(1):60-7.

30. Fabíola M, Maria GM, João D, Florência V, Cristina M, Ana ID, Cristina AF, José GB, Luís GP. Antioxidant capacity of the essential oils from Lavandula luisieri, L. stoechas subsp. Iusitanica, L. stoechas subsp. Iusitanica X L. Iuisieri and L.viridis grown in Algarve (Portugal). J Essent Oil Res. 2013:21:327-36.

31. Gâmez MJ, Jimenez J, Risco S, Zarzuelo A. Hypoglycemic activity in various species of the genus Lavandula. I: Lavandula stoechas $L$ and Lavandula multifida L. Pharmazie. 1987;10(42):706-7.

32. Gilani AH, Aziz N, Khan MA, Shaheen F, Jabeen Q, Siddiqui BS, Herzig JW. Ethnopharmacological evaluation of the anticonvulsant, sedative and antispasmodic activities of Lavandula stoechas L. J Ethnopharmacol. 2000;71:161-7.

33. Gill AO, Delaquis $P$, Russo $P$, Holley RA. Evaluation of antilisterial action of cilantro oil on vacuum packed ham. Int J Food Microbiol. 2002;73:83-92.

34. Gören AC, Topçu G, Bilsel G, Bilsel M, Aydoğmuş Z, Pezzuto JM. The chemical constituents and biological activity of essential oil of Lavandula stoechas ssp. stoechas. Z Naturforsch. 2002;57:797-800.

35. Gursoy UK, Gursoy M, Gursoy OV, Cakmakci L, Kononen E, Uitto VJ. Antibiofilm properties of Satureja hortensis L. essential oil against periodontal pathogens. Anaerobe. 2009;15:164-7.

36. Haraguchi H, Saito T, Ishikawa H, Date H, Kataoka S, Tamura Y. Antiperoxidative components in Thymus Vulgaris. Planta Med. 1996;62:217-21.

37. Hendry ER, Worthington T, Conway BR, Lambert PA. Antimicrobial efficacy of eucalyptus oil and 1,8-cineole alone and in combination with chlorhexidine digluconate against microorganisms grown in planktonic and biofilm cultures. J Antimicrob Chemother. 2009:64:1219-25.

38. Hidalgo PJ, Ubera JL, Tena MT, Valcarcel M. Determination of the carnosic acid content in wild and cultivated Rosmarinus officinalis. J Agric Food Chem. 1998:46:2624-7.
39. Hnia C, Chokri M, Mohamed B. Genetic diversity and population structure in Tunisian Lavandula stoechas L. and Lavandula multifida L. (Lamiaceae). Biochem Syst Ecol. 2008;36:349-59.

40. Hobbs WR, Rall TW, Verdoorn TA. Hypnotics and sedatives: ethanol. In: Hardman JG, Limbird LE, Molinoff PB, Ruddon RW, Gilman AG, editors. Goodman and Gillman's the pharmacologial basis of therapeutics. New York: The McGraw-Hill Companies, Inc.; 1996. p. 361-83.

41. Jamila F, Mostafa E. Ethnobotanical survey of medicinal plants used by people in oriental Morocco to manage various ailments. J Ethnopharmacol. 2014;154:76-87.

42. Kaplan M, Mutlu EA, Benson M, Fields JZ, Banan A, Keshavarzian A. Use of herbal preparations in the treatment of oxidant mediated inflammatory disorders. Ther Med. 2007:15:207-16.

43. Krishna A, Tiwari R, Kumar S. Aromatherapy-an alternative health care through essential oils. J Med Aromat Plant Sci. 2000;22:798-804.

44. Lagouri V, Boskou D. Nutrient antioxidants in oregano. Int J Food Sci. 1996; 47:439-97.

45. Lamaison JL, Petitjean FC, Carnat A. Medicinal Lamiaceae with antioxidant properties, a potential source of rosmarinic acid. Pharm Acta Helv. 1991; 66(07):185-8 [Article in French].

46. Lee CJ, Chen LG, Chang TL, Ke WM, Lo YF, Wang CC. The correlation between skin-care effects and phytochemical contents in Lamiaceae plants. Food Chem. 2011;124:833-41.

47. Lim TK. Edible medicinal and non medicinal plants. Springer Dordrecht Heidelberg New York London Library of Congress: springer edition, vol. 8; 2014.

48. Mahboubi M, Kazempour N. The antimicrobial activity of essential oil from Perovskia Abrotanoides karel and its main components. Ind J Pharm Sci. 2009;71:343-7.

49. Maia MF, Moore SJ. Plant-based insect repellents: a review of their efficacy, development and testing. Malar J. 2011;10(1):S11.

50. Malenčić DJ, Gašić O, Popović M, Boža P. Screening for antioxidant properties of Salvia reflexa Hornem. Phytother Res. 2000;14:546-8.

51. Manzoor IM, Khan MA. Isolation of new compounds from Lavandula stoechas. In: Said M, editor. Hamdard pharmacopoeia. Karachi: Hamdard National Foundation; 1969. p. 480-2.

52. Marcum DB, Hanson BR. Effect of irrigation and harvest timing on peppermint oil yield in California. Agric Water Manag. 2006;82:118-28.

53. María de Cortes SM, Javier T. Mediterranean wild edible plants: ethnobotany and food composition tables. New York: Springer; 2016.

54. Marinova EM, Yanishlieva NV. Antioxidative antivity of extracts from selected species of the family lamiaceae in sunflower oil. Food Chem. 1997:58:245-8.

55. Mazyad SAM, Soliman M. Laboratory evaluation of the insecticidal activity of camphor on the development of Oestrusovis larvae. J Egypt Soc Parasitol. 2001;31(3):887-92.

56. Melpomeni S, Chedly A, Eugene K. Essential oil variation of Lavandula stoechas L. ssp. Stoechas growing wild in Crete (Greece). Biochem Syst Ecol. 1996;24(3):255-60.

57. Messaoud C, Chograni H, Boussaid M. Chemical composition and antioxidant activities of essential oils and methanol extracts of three wild Lavandula L. species. Nat Prod Res. 2012;26(21):1976-84.

58. Mohd AS, Mohd K, Juber A, Siddiqui B, Usama A, Farogh A, Mohd MK, Mohammad A, Asad A. Review article: Lavandula stoechas (Ustukhuddus): a miracle plant. J Innov Pharm Biol Sci. 2016;3(1):96-102.

59. Mourey A, Canillac N. Anti-Listeria monocytogenes activity of essential oils components of conifers. Food Control. 2002;13:289-92.

60. Msaada K, Salem N, Tammar S, Ammami M, Saharkhiz MJ, Debiche N, Limam F, Marzouk B. Essential oil composition of Lavandula dentata, $L$ stoechasand $L$ multifida cultivated in Tunisia. J Essent Oil-Bear Plants. 2012;15(6):1030-9.

61. Muñoz BJ, Arrillaga I, Segura J. Essential oil variation within and among natural populations of Lavandula latifolia and its relation to their ecological areas. Biochem Syst Ecol. 2007:35:479-88.

62. Naghibi F, Mosaddegh M, Motamed MS, Ghorbani A. Labiatae Family in folk medicine in Iran: from ethnobotany to pharmacology. Iran J Pharm Res. 2005:2:63-79

63. Novais MH, Santos I, Mendes S, Pinto-Gomes C. Studies on pharmaceutical ethnobotany in Arrabida Natural Park (Portugal). J Ethnopharmacol. 2004;93: 183-95.

64. Oraib SN, Amani AA, Ahmad EO, Mohammad O. Floristic features, distribution, and ethnobotany of plants gathered and used by local people from the Mediterranean forest in Northern Jordan. Ethnobot Res Appl. 2014;12:385-96. 
65. Ozcelik B, Lee JH, Min DB. Effects of light, oxygen and pH on the 2,2diphenyl-Ipicrylhydrazyl (DPPH) method to evaluate antioxidants. J Food Sci. 2003;68:487-90.

66. Perry NB, Anderson RE, Brennan NJ, Douglas MH, Heane AJ, Mc Grimpsey JA, Smallfield BM. Essential oil from Dalmatian sage (Salvia officinalis L.), variations among individuals, plant parts, seasons and sites. J Agric Food Chem. 1999;47:2048-54.

67. Polat R, Satıl F. An Ethnobotanical survey of medicinal plants in Edremit Gulf (Balıkesir- Turkey). J Ethnopharmacol. 2012;139:626-41.

68. Porto CD, Decorti D, Kikic I. Flavour compounds of Lavandula angustifolia L. to use in food manufacturing: comparison of three different extraction methods. Food Chem. 2009;112:1072-8.

69. Ristocelli D, Tomi F, Casanova J. 13C-NMR as tool for identification and enantiomeric differentiation of major terpenes exemplified by the essential oil of Lavandula stoechas L. ssp. stoechas. Flavour Fragrance J. 1999;13:154-8.

70. Ruoyun Y, Yali S, Shuchiu S, Shengchi C, Sungyan H, Jiunncheng L. Evaluation of the antibacterial activity of leaf and twig extract sofst out camphor tree, Cinnamomum kanehirae, and the effects on immunity and disease resistance of white shrimp, Litopenaeus vannamei. Fish Shellfish Immun. 2009;27(1):26-32.

71. Sarac N, Ugur A. The in vitro antimicrobial activities of the essential oils of some Lamiaceae species from Turkey. J Med Food. 2009;12(4):902-7.

72. Sariri R, Seifzadeh S, Sajedi RH. Anti-tyrosinase and antioxidant activity of Lavandula sp. extracts. Pharmacology. 2009;3:319-26.

73. Sarri M, Mouyet FZ, Benziane M, Cheriet A. Traditional use of medicinal plants in a city at steppic character (M'sila, Algeria). J Pharm Pharmacognosy Res. 2014;2(2):31-5.

74. Sebai H, Selmi S, Rtibi K, Gharbi N, Sakly M. Protective effect of Lavandula stoechas and Rosmarinus officinalis essential oils against reproductive damage and oxidative stress in alloxan-induced diabetic rats. J Med Food. 2014;18(2):241-9.

75. Sebai H, Selmi S, Rtibi K, Souli A, Gharbi N, Sakly M. Lavender (Lavandula stoechas L.) essential oils attenuate hyperglycemia and protect against oxidative stress in alloxan-induced diabetic rats. Lipids Health Dis. 2013; 12(1):189.

76. Selmi S, Jallouli M, Gharbi N, Marzouki L. Hepatoprotective and renoprotective effects of lavender (Lavandula stoechas L.) essential oils against malathion-induced oxidative stress in young male mice. J Med Food. 2015;18(10):1103-11.

77. Shikha S. A review on pharmacological uses of essential oil. Int J Curr Pharm Rev Res. 2015;6(1):71-9.

78. Skoula M, Abidi C, Kokkalou E. Essential oil variation of Lavandula stoechas L ssp. stoechas growing WildinCrete (Greece). Biochem Syst Ecol. 1996;24(3): 255-60.

79. Soković M, Marin PD, Brkić D, Griensven LJ. Chemical composition and antibacterial activity of essential oils of ten aromatic plants against human pathogenic bacteria. Food. 2007;1:220-6.

80. Soumeya K, Tahar D, Mohamed T, Hafidha M, Aicha K, Chabane C. Evaluation of phytochemicals, antioxidant and cytotoxic activities of Lavandula Antineae Maire endemic medicinal plant from Algeria. Asian J Pharmaceut Res Health Care. 2014;6:24-31.

81. Steven D, Ehrlich NMD. Solutions acupuncture, a private practice specializing in complementary and alternative medicine. Healthcare Network: Phoenix; 2009.

82. Sultan Giray E, Saliha K, Alpaslan Kaya D, Murat T, zgür S, Memet I. Comparing the effect of sub-critical water extraction with conventional extraction methods on the chemical composition of Lavandula stoechas. Talanta. 2008;74:930-5

83. Tahraoui A, El Hilaly J, Israili ZH, Lyoussi B. Ethnopharmacological survey of plants used in the traditional treatment of hypertension and diabetes in southeastern Morocco (Errachidia province). J Ethnopharmacol. 2007;110: 105-17.

84. Tardío JV, Pardo-De-Santayana M, Morales R. Ethnobotanical review of wild edible plants in Spain. Bot J Linn Soc. 2006;152:27-71.

85. Tim MU, Stephen LJ. A revision of native Moroccan species of Lavandula L. section Pterostoechas Ging.(Lamiaceae). Taxon. 2002;51:309-27.

86. Topal U, Sasaki M, Goto M, Otles S. Chemical compositions and antioxidant properties of essential oils from nine species of Turkish plants obtained by supercritical carbon dioxide extraction and steam distillation. Int J Food Sci Nutr. 2008:59:619-34.
87. Ulubelen A, Olcay Y. Triterpenoids from Lavandula stoechas. Fitoterapia. 1989;60:475-6.

88. Xaver H, Andary C. Polyphenols of Lavandula stoechas L. Bulletin Liaison Group Polyphenols. 1988;133:624-6.

89. Zaheer UK, Asif SM. Antibacterial potentials of some constituents of Lavandula stoechas L. Pak J Bot. 2002;34(4):359-66.

90. Zrira S, Benjilali B. The constituents of the oils of Lavandula stoechas L. SSp. atlantica Br.-BI. and L. stoechas ssp. stoechas from Morocco. J Essent Oil Res. 2003:15:68-9.

91. Zuzarte M, Goncalves MJ, Cavaleiro C, Cruz MT, Benzarti A, Marongiu B, Maxia A, Piras A, Salqueiro L. Antifungal and anti-inflammatory potential of Lavandula stoechas and Thymus herba-barona essential oils. Ind Crop Prod. 2013:44:97-103

\section{Publisher's Note}

Springer Nature remains neutral with regard to jurisdictional claims in published maps and institutional affiliations.

\section{Submit your manuscript to a SpringerOpen ${ }^{\circ}$ journal and benefit from:}

- Convenient online submission

- Rigorous peer review

- Open access: articles freely available online

- High visibility within the field

- Retaining the copyright to your article

Submit your next manuscript at $\boldsymbol{\nabla}$ springeropen.com 